\title{
Involvement of the Endothelin System in Experimental Critical Hind Limb Ischemia
}

\author{
Charles-Edouard Luyt,* Delphine Lepailleur-Enouf,* Cédric-J. Gaultier, \\ Olivier Valdenaire, Gabriel Steg, and Jean-Baptiste Michel \\ Institut National de la Santé et de la Recherche Medicale, Paris, France \\ Accepted July 23, 2000.
}

\begin{abstract}
Background: Endothelin-1 (ET-1) is involved in the pathogenesis of several ischemic diseases. We investigated the hypotheses that ET- 1 is involved in the pathogenesis of experimental critical hind limb ischemia and that ET-1 receptor antagonists have a protective effect.

Materials and Methods: Critical hind limb ischemia was achieved by exclusion of the femoral artery and embolization of collateral vessels in rats. The induction of endothelin system components by ischemia was analyzed by reverse transcription-polymerase chain reaction (RT-PCR) (mRNAs) and immunoassay (peptides) in the plasma and ischemic muscles $5 \mathrm{hr}$ (H5), 5 days (D5) and 14 days (D14) after ischemia. Two groups of rats received $100 \mathrm{mg} / \mathrm{kg} /$ day of either Bosentan, a mixed $\mathrm{ET}_{\mathrm{A} / \mathrm{B}}$ receptor antagonist $(n=12)$, or LU 135252, a selective $\mathrm{ET}_{\mathrm{A}}$ receptor antagonist $(n=9)$, and a control group without treatment $(n=12)$ served as control. Muscle blood flow and ischemia were monitored in the ischemic limb by
\end{abstract}

laser Doppler and phosphorylase activity, respectively.

Results: The procedure induced an $80 \%$ decrease in muscle blood flow and complete suppression of phosphorylase activity without necrosis. At day 14, the tissue blood flow remained reduced by $70 \%$ and phosphorylase activity was suppressed completely. There was up-regulation of preproendothelin-1, preproET-3, endothelin converting enzyme-1, and $\mathrm{ET}_{\mathrm{A}} \cdot \mathrm{ET}_{\mathrm{B}}$ receptor mRNAs in ischemic muscle at day 5 and day 14 was accompanied by an increase in muscle concentration of ET-1 at day 5, without significant changes in plasma endothelin. Treatment with Bosentan and LU 135252 increased tissue blood flow and reduced muscle ischemia at day 14 . Conclusions: Tissue production of ET- 1 is up-regulated in experimental critical hind limb ischemia. Inhibition of the endothelin system by a mixed $\mathrm{ET}_{\mathrm{A} / \mathrm{B}}$ receptor antagonist may protect, at least in part, against muscle injury.

\section{Introduction}

Despite percutaneous or surgical revascularisation, morbidity and mortality of critical leg ischemia remain high (1). In recent years, several alternatives to surgery have been developed, among which therapeutic angiogenesis using growth factors or gene therapy appears promising $(2,3)$. An alternative could be the

Address correspondence and reprint requests to: Dr. JeanBaptiste Michel, Institut National de la Santé et de la Recherche Medicale U460, Cardiovascular Remodeling, UFR X. Bichat, 16 rue H. Huchard, 75018 Paris, France. Phone: 33-1-44-85-61-60;

${ }^{*}$ C.E. Luyt and D. Lepailleur-Enouf contributed equally to this work.

Fax: (33)-1-44-85-61-57; E-mail: $\underline{\text { u460@bichat.inserm.fr }}$ use of specific vasodilators. Fabre and coworkers (4) recently showed that treatment with quinapril improved blood flow and promoted angiogenesis in a model of critical leg ischemia in mice.

Endothelin-1 (ET-1) is the most powerful endogenous vasoconstrictor known (5). Produced constitutively by endothelial cells, its synthesis can be induced in various non-endothelial cells by hypoxia, peptides, and other factors (6). The biological effects of endothelin involve various molecular components, including peptides, endothelin converting enzyme, and endothelin receptor isoforms. Its physiological role in the cardiovascular system is not fully understood, but its induction plays a major role in several ex- 
perimental and human ischemic conditions, such as myocardial infarction (7) or cerebral vasospasm after hemorrhage (8). Over-expression of endothelin system components can be induced in myocardium in ischemic heart failure (9), in respiratory muscles during septic shock (10), and in hind limb muscle after ischemia and reperfusion (11). Nevertheless, the involvement of the different components of the endothelinergic system have never been explored in chronic critical muscle ischemia.

Several endothelin receptor antagonists appear to have a beneficial effect in experimental models of ischemia $(7,8,12,13)$, suggesting that tissue production of ET- 1 during ischemia may be involved in the chronic reduction of blood flow, as well as the pathogenesis of cell injury. Inhibition of the endothelin system may have protective effects in these situations.

The aims of the present study were to develop a new, simple, and reproducible model of chronic critical hind limb ischemia in the rat, to investigate the implication of the endothelin system in muscle ischemia. Dramatic blood flow reduction and muscle ischemia without necrosis were induced by femoral artery ligation associated with embolisation of the collateral vessels originating from the internal iliac artery. Up-regulation of the endothelin system was explored by analysis of the preproET- 1 , endothelin converting enzyme-1 (ECE-1), and ET receptors' mRNAs and ET-1 peptide concentrations. Involvement of the endothelin system in chronic ischemia was confirmed pharmacologically by showing a partial protective effect of endothelin antagonists.

\section{Materials and Methods}

Surgical Procedure

Male Lewis rats (Iffa-Credo L'arbresle, France), weighing 280-320 g and aged 10 weeks, were used for this study. The experimental design complied with the Principles of Laboratory Animal Care formulated by the National Society for Medical Research and the Guide for the Care and Use of the Laboratory Animals (NIH publication N.86-23 revised 1989. Authorization $\mathrm{N}^{\circ}$ 00577, Paris, France). The animals were anesthetized with $50 \mathrm{mg} / \mathrm{kg}$ of sodium pentobarbital. Under a surgical microscope, an incision was made in the right groin, and the right external iliac and femoral arteries were dissected free from the origin of the ex- ternal iliac artery (i.e., the termination of the common iliac artery) to the end of the femoral artery. All branches of the femoral and external iliac artery were thermo-coagulated. External iliac artery ligation alone did not induce ischemia in rats, because of the immediate recruitment of collateral vessels originating from the ipsilateral internal iliac artery. To achieve critical hind limb ischemia, 10000 microspheres (Cytodex 2; Amersham Pharmacia Biotech, Orsay, France), of diameter $150 \mu \mathrm{m}$, were injected into the internal iliac artery via a retrograde catheter inserted through the external iliac artery to partly suppress collateral flow (Fig. 1). The catheter was then removed, the external iliac artery ligated and excised, the clamp on the common iliac artery removed, and the skin sutured. The contralateral hind limb was sham-operated by incision of the skin and dissection of the external iliac and femoral arteries.

To detect ET receptors and tissue production of ET- 1 and ECE-1 in ischemic muscles, 20 rats underwent the surgical procedure and were sacrificed $5 \mathrm{hr}, 1,5$ and 14 days later $(n=5$ at each time point). Tibialis anterior muscles (ischemic and non-ischemic) were taken for reverse transcription-polymerase chain reaction (RT-PCR) analysis and ET- 1 tissue assay. Blood was collected before sacrifice for plasma ET-1 immunoassay.

To evaluate the effect of endothelin receptor antagonists, three groups of animals underwent the surgical procedure. In one group, 12 rats were treated with $100 \mathrm{mg} / \mathrm{kg} /$ day per os of Bosentan, a mixed $\mathrm{ET}_{\mathrm{A} / \mathrm{B}}$ receptor antagonist (14), for 19 days, starting 5 days before induction of ischemia (until the end of the study period). In a second group, nine rats received $100 \mathrm{mg} / \mathrm{kg} /$ day per os of LU 135252, a specific $\mathrm{ET}_{\mathrm{A}}$ receptor antagonist (7), 5 days before and 14 days after the surgical procedure. The last group of 12 rats were operated on and received the vehicle only (control group). All three groups were evaluated 14 days after induction of ischemia by measurement of tissue blood flow and detection of muscle phosphorylase activity.

\section{Tissue Blood Flow}

A laser-doppler flowmeter (Perimed, Sweden) was used for functional evaluation of tissue blood flow $(15,16)$. Three muscles (tibialis anterior, biceps femoris, and adductor) on each 


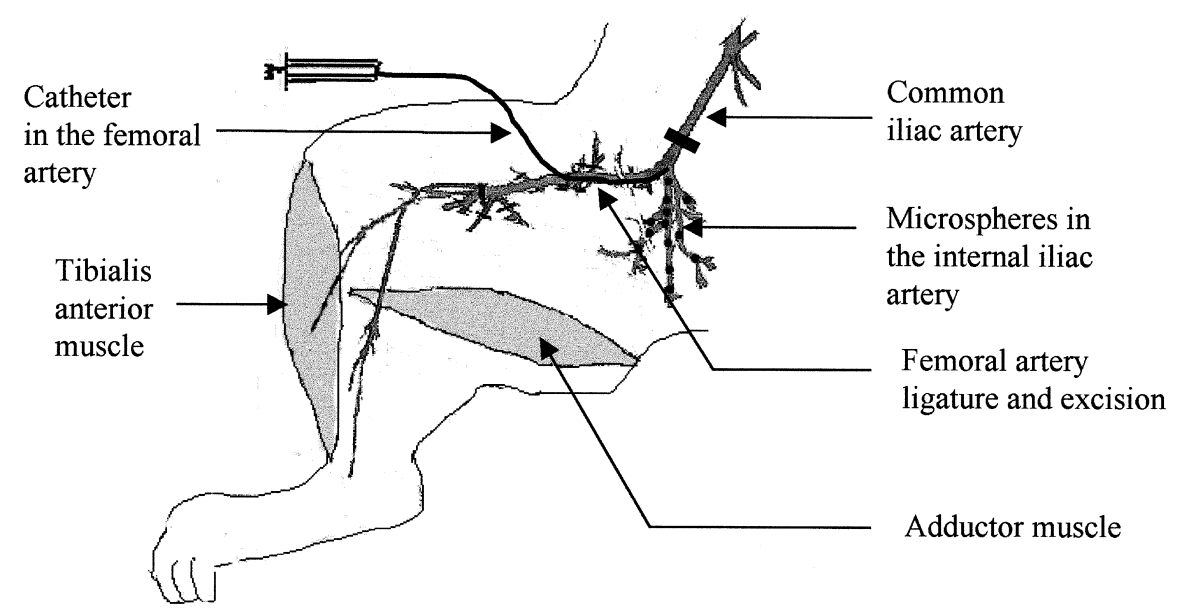

Fig. 1. Diagram of the experimental procedure. In grey: the arterial system of the rat hind limb. The common iliac artery was temporarily clamped, a catheter was inserted through the femoral artery, and the microspheres then were injected into the

leg were studied. After skin incision, the probe was placed on the muscle and a signal was recorded. The Doppler signal was taken as an index of microvascular perfusion of the muscle area under the probe $(6 \mathrm{~mm})$ and at a depth of $1 \mathrm{~mm}$. Three to five measurements on each muscle were recorded and averaged. Results represented "residual blood flow", such as the muscular blood flow in the ischemic hind limb, expressed as a percentage of the sham-operated hind limb. For each animal, three determinations were performed: before surgery, immediately after surgery, and 14 days later.

\section{Histo-enzymology}

Ischemic and non-ischemic extensorum digitorum longus (EDL) muscle samples were taken from the control group, from the bosentantreated group, and from the LU 135252-treated groups at day 14. Samples were frozen in liquid nitrogen-cooled isopentane and stored at $-80^{\circ} \mathrm{C}$. The muscles were cut into $8 \mu \mathrm{m}$ sections using a cryostat and sections were stained with hematoxylin and eosin for topographical examination. Additional sections were stained with $1 \%$ lugol substrate to study glycogen phosphorylase activity (17). Phosphorylase activity indicates muscle glycogenolysis. With this procedure, metabolically active skeletal muscle fibers stain brown; whereas, a yellow stain indicates absence of metabolic activity (17). internal iliac artery. The femoral artery then was ligated and excised. The muscles colored in grey represent two of the muscles tested for functional evaluation; the third muscle (biceps femoris) being out of view on the other side of the hind limb.

\section{Exploration of the Endothelin System in Ischemia}

PLASMA ENDOTHELIN-1. $6 \mathrm{ml}$ of blood were collected from the aorta on EDTA and centrifuged at $2000 \mathrm{~g}$, for $20 \mathrm{~min}$ at $4^{\circ} \mathrm{C} .2 \mathrm{ml}$ of the plasma were stored at $-80^{\circ} \mathrm{C}$ until assay. Then, animals were sacrificed. ET-1 concentration was determined by immunoassay (Parameter; R\&D Systems, Abingdon, GB) after protein precipitation and plasma concentration $(8 \mathrm{X})$.

To confirm the efficacy of treatment with endothelin antagonists, 20 additional rats $(n=$ 5 per group) were treated with Bosentan, underwent surgical procedure, and were sacrificed $5 \mathrm{hr}, \mathrm{l}, 5$ and 14 days after surgery. Blood was collected and plasma ET-1 was determined.

MUSCLE ET-1 LEVELS. Tibialis anterior muscles (ischemic and sham-operated) were excised at different times ( $5 \mathrm{hr}$, day 5 , and day 14), snapfrozen in liquid nitrogen, and stored at $-80^{\circ} \mathrm{C}$ until assay. ET- 1 was extracted as previously described (18). Briefly, $200 \mathrm{mg}$ of muscle were homogenized in $4 \mathrm{M}$ guanidine thiocyanate/ $0.1 \%$ trifluoroacetic acid on ice. An aliquot was taken for protein measurement (Bio-Rad, Hercules, Ivry sur Seine, France). The homogenate was then centrifuged at $5000 \mathrm{~g}$ for $20 \mathrm{~min}$ at $4^{\circ} \mathrm{C}$. The supernatant was then loaded on a Sep Pak C18 cartridge. The cartridge was prewashed with $4 \mathrm{ml}$ of $\mathrm{H}_{2} \mathrm{O}$ and $4 \mathrm{ml}$ of $20 \%$ methanol. The absorbed peptides were eluted with $1.5 \mathrm{ml}$ of $90 \%$ ethanol. Recovery of the whole procedure was expected to 
be $66 \%$. ET- 1 tissue levels were determined by an immunoassay (Parameter, R\&D Systems Waters Corporation Milford, MA, USA). Results were expressed as $\mathrm{pg} / \mathrm{mg}$ of total protein.

MUSCLE LEVELS OF PREPROET-1, PREPROET-3, ECE-1, ET $\mathrm{A}_{\mathrm{A}}$ AND $\mathrm{ET}_{\mathrm{B}}$ RECEPTOR MRNA. For RT-PCR analysis, the tibialis anterior muscles were excised from the ischemic side, and the sham-operated side, and snap-frozen in liquid nitrogen. Total muscle RNA was extracted using a previously described method (19). The quality of isolated mRNA was verified by gel electrophoresis. PreproET-1, preproET-3, ECE-1, $\mathrm{ET}_{\mathrm{A}}$ and $\mathrm{ET}_{\mathrm{B}}$ receptors, and glyceraldehyde-3phosphate deshydrogenase (GAPDH) mRNA expression were quantified in muscles by comparative RT-PCR. $1 \mu \mathrm{g}$ of total RNA was primed with $1 \mu \mathrm{g}$ oligo (dT) (Amersham Pharmacia Biotech, Orsay, France) and reverse transcribed in the presence of Moloney murine leukemia virus reverse transcriptase (GIBCO, Cergy Pontoise, France). The cDNA was amplified by PCR using specific oligonucleotide primers for rat preproET-1 (5), preproET-3 (20), ECE-1 (21), ET and $\mathrm{ET}_{\mathrm{B}}$ receptors, and GAPDH (22) (Table 1). Double-strand cDNAs were synthesized and amplified using 1.25 U Taq polymerase (GIBCO), $20 \mathrm{mM}$ Tris- $\mathrm{HCl}(\mathrm{pH} \mathrm{8.0)}, 50 \mathrm{mM} \mathrm{KCl}, 0.2 \mathrm{mM}$ of dNTP, 10 pmol of each primer, $1.5 \mathrm{mM}$ of $\mathrm{MgCl}^{2}, 4 \times 10^{5} \mathrm{cpm}$ of ${ }^{33} \mathrm{P}$-labeled primer (Isoptochim, Ganagobie, France) in a $25 \mu \mathrm{l}$ reaction final volume. The amplification was carried out in a DNA thermal cycler (Techne) using 31 cycles for ppET- $1\left(94^{\circ} \mathrm{C}, 30 \mathrm{sec} ; 62^{\circ} \mathrm{C}, 1 \mathrm{~min}\right.$; $72^{\circ} \mathrm{C}$, $\left.1 \mathrm{~min}\right), 30$ cycles for ppET- $3\left(94^{\circ} \mathrm{C}, 30 \mathrm{sec}\right.$; $\left.55^{\circ} \mathrm{C}, 1 \mathrm{~min} ; 72^{\circ} \mathrm{C}, 1 \mathrm{~min}\right), 26$ cycles for ECE-1 $\left(94^{\circ} \mathrm{C}, 30 \mathrm{sec} ; 55^{\circ} \mathrm{C}, 1 \mathrm{~min} ; 72^{\circ} \mathrm{C}, 1 \mathrm{~min}\right), 30 \mathrm{cy}-$ cles for $\mathrm{ET}_{\mathrm{A}}$ receptor $\left(94^{\circ} \mathrm{C}, 30 \mathrm{sec} ; 59^{\circ} \mathrm{C}, 1 \mathrm{~min}\right.$; $\left.72^{\circ} \mathrm{C}, 1 \mathrm{~min}\right), 28$ cycles for $\mathrm{ET}_{\mathrm{B}}$ receptor $\left(94^{\circ} \mathrm{C}, 30\right.$ sec; $\left.62^{\circ} \mathrm{C}, 1 \mathrm{~min} ; 72^{\circ} \mathrm{C}, 1 \mathrm{~min}\right)$ and 18 cycles for GAPDH $\left(94^{\circ} \mathrm{C}\right.$, $30 \mathrm{sec} ; 55^{\circ} \mathrm{C}, 1 \mathrm{~min} ; 72^{\circ} \mathrm{C}$, $1 \mathrm{~min})$.

PCR fragments were analyzed by $8 \%$ polyacrylamide gel electrophoresis and revealed by ethidium bromide staining. Bands were cut out, dissolved in periodic acid ( $25 \mathrm{mM})$, and counted using a RackBeta liquid scintillation counter (Wallac Oy Turku, Finland). PCR amplification was verified to be exponential, and the amplification products were proportional to the sample input. PreproET-1, preproET-3, ECE-1, $\mathrm{ET}_{\mathrm{A}}$ and $\mathrm{ET}_{\mathrm{B}}$ receptors mRNA expressions were calculated by normalizing to GAPDH mRNA.

\section{Statistical Analysis}

All results are expressed as means \pm standard error of the mean (SEM). Comparisons for the ET-1 mRNA, and protein and residual blood flow between ischemic and control muscles were performed using a factorial two-way ANOVA. Any differences detected were analyzed using a one-factor ANOVA with post hoc comparisons by the Fisher test. A Chi-2 test was performed to compare the frequency of positive phosphorylase activity between the groups. A $p$-value $<0.05$ was considered statistically significant.

\section{Results \\ Model of Hind Limb Ischemia}

After surgery, all animals presented ischemia at rest and muscular atrophy without skin necrosis. Functional evaluation before the induction

Table 1. Primers sequences used in this study

\begin{tabular}{|c|c|c|c|}
\hline Product & Sense & Antisense & Size (bp) \\
\hline PreproET-1 & 5'-TCTCTGCTGTTTGTGGCTTTC-3' & 5'-TCGGAGTTCTTTGTCTGTTTG-3' & 368 \\
\hline PreproET-3 & 5'-GGAAATGCTGGGCAGGAG-3' & 5'-CAGGTGCAGTTTCCGACTTC-3' & 402 \\
\hline ECE-1 & 5'-CAAGCTCCTTTCTCGACCA-3' & 5' -TTACCCAGTTCTGGTAGGCC-3' & 856 \\
\hline $\mathrm{ET}_{\mathrm{A}}$ receptor & 5'-GGACAGGTACAGAGCAGTGG-3' & 5'-CATTCATGGGGACCGAGG-3' & 662 \\
\hline $\mathrm{ET}_{\mathrm{B}}$ receptor & 5'-ACAAGCTGCTGGCAGGGG-3' & 5'-AACAGAGGGCAAACACGAGG-3' & 426 \\
\hline GAPDH & 5'-GTGAAGGTCGGAGTCAACG-3' & 5'-GGTGAAGACGCCAGTGGACTC-3' & 299 \\
\hline
\end{tabular}

bp, base pairs; ET, endothelin; ECE-1, endothelin converting enzyme-1; GAPDH, glyceraldehyde-3-phosphate dehydrogenase; Preproendothelin-1, 
of ischemia showed that muscular blood flow was similar in the two hind limbs for each muscle tested. Immediately after surgery, the residual blood flow of the ischemic hind limbs (compared with the sham-operated hind limb) decreased from $100 \%$ to $15 \pm 1.3 \%$ for the biceps femoris, $20 \pm 3 \%$ for the tibialis anterior, and $27 \pm 2.6 \%$ for the adductors. Fourteen days after surgery, the residual blood flow of the ischemic hind limb was $52 \pm 2.5 \%$ for the biceps femoris, $32 \pm 3.4 \%$ for the tibialis anterior, and $61 \pm 3.5 \%$ for the adductors. Similar results were obtained when residual blood flows were compared with ipsilateral pre-surgery values.

Fourteen days after surgery, there was no phosphorylase activity in the ischemic muscles, as shown by the diffuse yellow staining of muscle sections (Fig. 2E); whereas, the all normal muscles of the sham-operated side stained brown, indicating phosphorylase activity (Figure. 2D). The hematoxylin and eosinstained cross-sections of the ischemic muscles showed evidence of severe diffuse cellular ischemia, shown by the loss of normal muscle architecture, disappearance of the muscle nuclei, and inflammatory cell infiltration (Fig. 2B), compared with sections of normal muscle (Fig. 2A).

\section{Endothelin System in Ischemia}

PLASMA ET-1 LEVELs. Baseline plasma levels of ET-1 were very low in normal Lewis rats, approximatively $0.125 \mathrm{pg} / \mathrm{ml}$ (Fig. 3A). Plasma levels increased 3- to 4 -fold, $5 \mathrm{hr}$ after ischemia $(p<0.001)$, then decreased to twice baseline level at day 1 and remained stable thereafter.
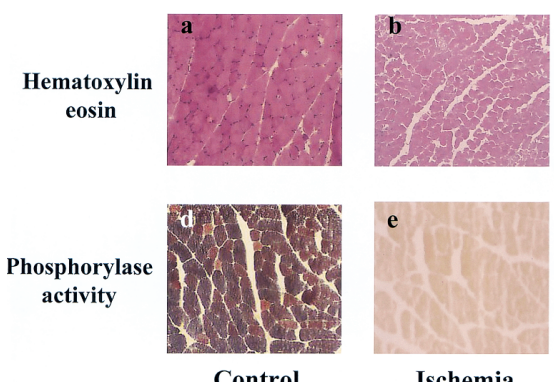

Ischemia
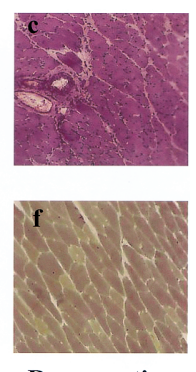

Regeneration
Fig. 2. Morphology. Sections of ischemic, normal and regenerated muscles stained with hematoxylin and eosin (2A, 2B and 2C, respectively) and for phosphorylase activity $(2 \mathrm{D}, 2 \mathrm{E}$ and $2 \mathrm{~F}$, respectively). In the regenerated muscles, the fibers appear darker and nuclei have reappeared in a central position (2C), compared with normal muscle (2A). Magnification $10 \mathrm{X}$.
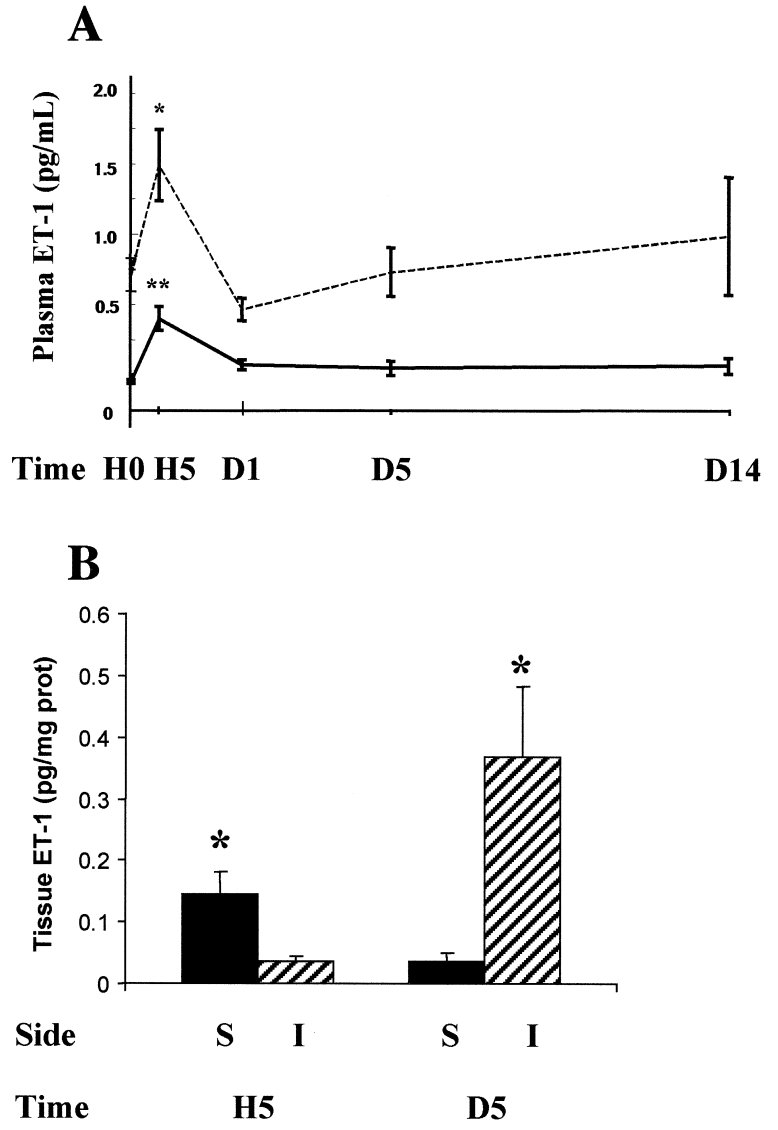

Fig. 3. Plasma and tissue endothelin-1 (ET-1) concentration. (A) Plasma levels of ET-1 before induction of ischemia (H0), 5hr (H5), and 1, 5 and 14 days (D1, D5 and D14, respectively) after surgery in control animals ( - ) and in bosentantreated animals (.......). *,$p<0.05$ in comparison with D 1. ${ }^{* *}, p<0.001$ in comparison with other times. (B) Endothelin-1 concentrations in ischemic (I) and sham-operated (S) muscles at $5 \mathrm{hr}$ (H5) and day 5 (D5). Results are expressed as picograms of endothelin-1 per mg of total proteins (pg/mg prot). ( $n=5$ per group. Mean \pm standard error of the mean, SEM).*, $p<0.05$, ischemic vs. sham.

Treatment with Bosentan for 5 days before induction of ischemia and throughout the experiment increased the plasma level of ET-1 (Fig. 3A). The kinetics of plasma ET-1 levels were similar in the Bosentan-treated group and in the control group. Despite a significant increase at $5 \mathrm{hr}$ vs. baseline, plasma levels were not significantly different at 1, 5 and 14 days.

MUSCle ENDOTHELIN-1 CONCENTRATIONS. Five hours after induction of ischemia, muscle concentration of ET-1 was significantly lower on the ischemic side than on the shamoperated side ( $p<0.05$; Fig. 3B). In contrast, muscle ET-1 concentration was significantly 
A
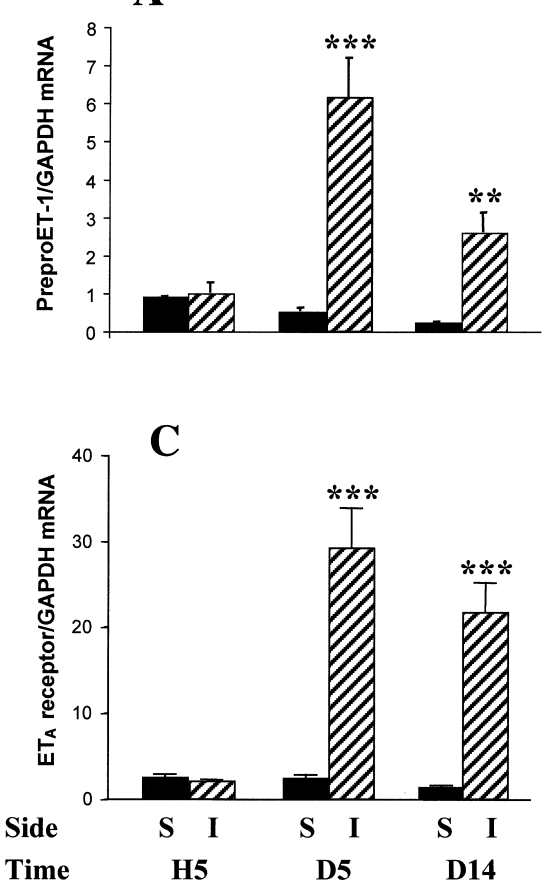

Fig. 4. Endothelin system component expression. Comparative reverse transcriptionpolymerase chain reaction (RT-PCR) of (A) preproET-1 mRNA, (B) ECE-1 mRNA, (C) ET $\mathrm{A}_{\mathrm{A}}$ and (D) $\mathrm{ET}_{\mathrm{B}}$ receptor mRNA normalized by glyceraldehyde-3-phosphate dehydrogenase

greater on the ischemic side at day 5 , with a 10-fold up-regulation of the peptide $(p<0.05$; Fig. 3B).

COMPARATIVE RT-PCR. Five hours after ischemia, there was no change in preproET-1 mRNA levels on the ischemic side, compared with the shamoperated side (Fig. 4A). Howewer, there was a 14fold increase of mRNA levels at day $5(p<0.0001)$ and a 11 -fold increase at day 14 ( $p<0.01$; Fig. 4A).

There was a slight increase in preproET-3 mRNA in the ischemic muscles, compared with sham-operated $5 \mathrm{hr}$ (from $2.93 \pm 0.25$ in controls to $5.07 \pm 0.27$ in ischemia, NS) and 5 days (from $3.3 \pm 0.34$ to $4.99 \pm 1.09$, NS) after induction of ischemia; on day 14 , there was a 4fold increase (from $2.35 \pm 0.27$ in controls to $9.97 \pm 1.49$ in ischemia, $p=0.001$; data not shown).

Comparative RT-PCR showed an increase in ECE-1 mRNA in ischemic muscles, similar to that of preproET-1. There was a decrease in mRNA levels $5 \mathrm{hr}$ after induction of ischemia $(p<0.01)$, followed by marked increase on

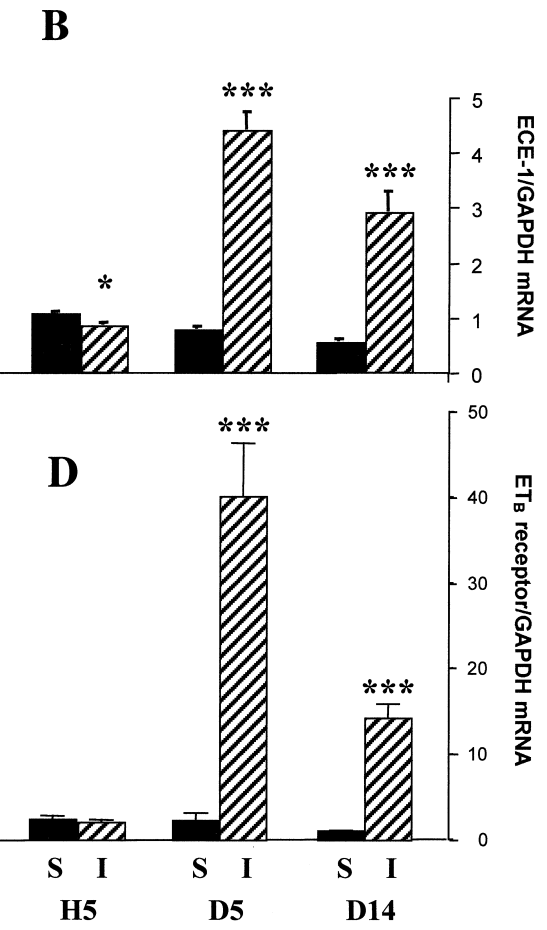

(GAPDH) mRNA, in ischemic (I) and shamoperated (S) muscles at 5 hr (H5), day 5 (D5) and day 14 (D 14). $n=5$ per group expressed as mean \pm standard error of the mean, SEM. ${ }^{*}, p<0.05,{ }^{* *}$, $p<0.01,^{* * *}, p<0.001$, ischemic vs. sham. ET, endothelin; ECE, endothelin converting enzyme-1

day 5 (6-fold, $p<0.0001$ ) and day 14 (5-fold, $p<0.001$; Fig. 4B). Similarly, $\mathrm{ET}_{\mathrm{A}}$ and $\mathrm{ET}_{\mathrm{B}}$ receptor mRNA increased 12 -fold and 16-fold, respectively, at day 5 and 17 -fold and 12.5-fold at day 14 (Fig. 4C and 4D, respectively).

\section{Effects of Endothelin System Blockade on Ischemia}

TISSUE BLOOD FLOW. There was no difference in blood flow between the three groups (control, Bosentan, and LU 135252-treated) before induction of ischemia (Fig. 5A). Immediately after ischemia, blood flow in the ischemic hind limb was reduced in the three groups $(p<0.0001)$. Nevertheless, the reduction in tissue blood flow was slightly more significant in LU 135252treated animals than in controls and Bosentantreated rats (residual blood flow: $16.8 \pm 1.3 \%$ in LU 135252-treated, vs. $23.4 \pm 1.9 \%$ in Bosentan-treated rats, and $21.2 \pm 1.3 \%$ in controls; $\mathrm{F}=4.5, p<0.05) .14$ days later, the residual blood flow in the ischemic hind limb was significantly greater in the Bosentan-treated (77.1 $\pm 3.2 \%)$ and LU 135252-treated $(72.4 \pm 3.9 \%)$ groups than in the control group $(48.2 \pm 2.7 \%$; 
A

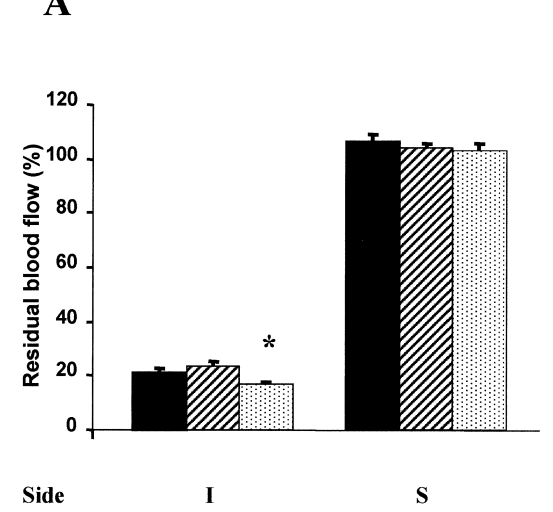

Fig. 5. Effects of endothelin antagonists on blood flow. (A) Residual blood flow (\% of ipsilateral pre-surgery values) observed in the ischemic (I) and sham operated (S) hind limbs in control, Bosentan-treated, and LU 135252-treated rats immediately after surgery (the individual values for each of the three muscles are pooled using an ANOVA for repeated measures). Results expressed as mean \pm standard error of the mean,

$p<0.001$ for both treatments vs. control; Fig. 5B). There was no significant difference between the effects of these two treatments.

PHOSPHORYLASE ACTIVITY. In the Bosentantreated group, three animals had complete regenera-tion of the EDL muscle, observed both with hematoxylin and eosin-staining (Fig. 2C) and with phosphorylase activity (Fig. 2F). Two animals showed partial regeneration of the EDL muscle, and the others showed diffuse ischemia. The reappearance of phosphorylase activity in muscles of the Bosentan-treated group was demonstrated by the brown staining of the regenerating fibers (Fig. 2F). The regenerating fibers in the Bosentan-treated group also appeared darker than degenerated fibers, when stained with hematoxylin and eosin, with reappearance of nuclei in a central cytoplasmic position (Fig. 2C) and not in the peripheral zone of the fiber as in control muscles (Fig. 2A).

In the LU 135252-treated group, one rat showed partial regeneration of the muscle, observed with hematoxylin and eosin-staining (Fig. 2C) and with phosphorylase activity (Fig. 2F), and the others showed diffuse ischemia (Fig. 2B and 2E). Altogether, 5 of 12 rats $(42 \%)$ of the Bosentan-treated animals showed partial or complete regeneration (as seen by phosphorylase activity) vs. 1 of 9 (11\%) and 0 of

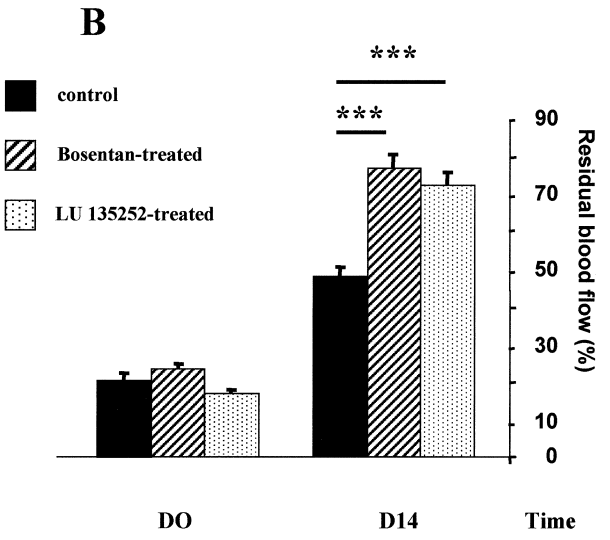

SEM. ${ }^{*}, p<0$.05, in comparison with other groups. (B) Residual blood flow (\% of contralateral hind limb values) observed immediately (D0) and 14 days (D14) after induction of ischemia (the individual values for each of the three muscles are pooled using an ANOVA for repeated measures). Results expressed as mean \pm standard error of the mean, SEM. ${ }^{* * *}$, $p<0.001$, in comparison with control group.

12 in the LU 135252-treated and control groups $(p<0.05)$, respectively.

\section{Discussion}

The present study used an original model of chronic critical hind limb ischemia in the rat. There are a few such models of chronic ischemia, which suffer several limitations: the surgical procedure may be cumbersome (23), or ischemia may be too severe (17), insufficient, or transient (24). In contrast, the present model is straightforward, reproducible, and generates chronic severe ischemia at rest, with protracted reduction in blood flow and muscular atrophy, somewhat akin to the critical limb ischemia seen in patients.

Whereas, the expression of mRNAs of the different endothelin system components was not acutely induced by ischemia (at $5 \mathrm{hr}$ ), preproET1 , as well as ECE-1, $\mathrm{ET}_{\mathrm{A}}$ and $\mathrm{ET}_{\mathrm{B}}$ receptor mRNAs were chronically overexpressed in chronic critical hind limb ischemia (at days 5 and 14), suggesting transcriptional upregulation triggered by chronic hypoxia (25). The overexpression of the mRNAs of the various components of the endothelin system components was associated with an increase in the muscle peptide concentration 5 days after induction of ischemia without detectable changes in plasma ET-1 concentrations. This 
strongly suggests that the tissue endothelin system plays a local pathophysiological, rather than a systemic, role. Such localized tissue involvement of the endothelin system already has been suggested in the physiological irreversible ischemia of the placenta at birth (26) and in localized cerebrovascular vasospasm secondary to subarachnoid hemorrhage (8).

The increase in preproET-1 mRNA expression is consistent with the previous observation in a model of acute ischemia/reperfusion (11). In that study, preproET-1 mRNA increase was observed somewhat earlier than in the present model, possibly due to the differences in the severity of ischemia (11).

ET-3 expression has been studied less than ET-1. It is known that ET-3 is present in the brain, the gastrointestinal tract, and the kidney, and that it plays a role in development (6). The induction of the ET- 3 gene has been described only in the retina of diabetic rats (27) and in the respiratory muscles of rats with septic shock (10). Our data suggest that chronic ischemia may be one trigger for the expression of the preproET-3 gene in skeletal muscle. Up-regulation of ECE-1 mRNA also has been previously described in respiratory muscles in experimental septic shock (10). To our knowledge, this is the first study that describes the up-regulation of ECE-1 mRNA synthesis in vivo in response to chronic ischemia in skeletal muscles.

Li and coworkers (25) demonstrated enhanced endothelin receptor gene expression by chronic hypoxia in lung. In the present study, an up-regulation of $\mathrm{ET}_{\mathrm{A}}$ and $\mathrm{ET}_{\mathrm{B}}$ receptor expression is observed in chronic ischemic muscle, suggesting the involvement of all components of the molecular endothelin system in the pathophysiology of muscle ischemia.

In agreement with clinical observations during acute myocardial ischemia (28), an early acute (at $5 \mathrm{hr}$ ) plasma release of ET- 1 was observed in our model. In view of the absence of any concomittant increase in preproET- 1 and ECE-1 mRNAs, this increase in plasma ET-1 concentration is probably due more to the release of tissue-stored peptide rather than to de novo synthesis. An increase in plasma ET- 1 levels was described previously in a model of ischemia/reperfusion in dogs (29). In this model, the authors found an increase in plasma ET-1 levels during reperfusion after infrarenal aortic cross-clamping, but not during ischemia alone (29).

In contrast, whereas preproET-1 and ECE-1 mRNA expression and tissue content increased later, no change in plasma ET-1 concentration was observed, suggesting once again the local involvement of the endothelin system. Due to their high affinity for the peptide (30), endothelin receptors that are overexpressed in the ischemic tissue, are probably the main local molecular effectors of peptide clearance. For example, endothelial expression of the endothelin receptors modulates the concentration of endothelin peptide in the culture medium in vitro (31) and in the plasma compartment in vivo (32). Conversely, the diffusion of the peptide through the endothelial barrier from the basal compartment, mimicking the interstitial compartment, to the apical compartment, mimicking the plasma compartment, is limited in vitro (33). The increase in ET-1 plasma levels induced by Bosentan treatment in rats, as in human (34), provides evidence of a decrease in the ET-1 clearance by its receptors, probably mainly by its endothelial receptors (32). In agreement with this concept, the overexpression of $\mathrm{ET}_{\mathrm{A}}$ and $\mathrm{ET}_{\mathrm{B}}$ receptors in ischemic muscle could explain, at least in part, the absence of increase in plasma ET-1 and, therefore, the local role of the endothelin system in ischemia. In view of the local tissue involvement of the endothelin system and its powerful vasoconstrictor effect (5), we tested the effects of endothelin antagonists in our model. Endothelin antagonists impact favorably upon blood flow as well as, at least for Bosentan, muscle regeneration. Such beneficial effects of endothelin antagonists have been reported already in experimental cerebral vasospasm (35) and in acute myocardial ischemia $(7,12)$. Bosentan was previously shown to be effective for attenuating vasoconstriction of the hind limb vascular bed provoked by ET-1 in cats (36). The difference observed between Bosentan and LU 135252, with respect to muscle regeneration, may be related to the specificity of receptor blockade, to the choice of doses, or to the effect of $\mathrm{ET}_{\mathrm{B}}$ receptors on blood flow $(37,38)$. Nevertheless, because of the high affinity of endothelin for its receptors, we can never be sure to be of the maximal biological effect of peptide antagonism.

Our design did not permit the discrimination between a functional vasodilator effect and a true structural angiogenic effect of endothelin antagonists in ischemia. In a recent study comparing vascular endiothelial growth factor (VEGF), an angiogenic growth factor, to an angiotensin converting enzyme (ACE) in- 
hibitor, a vasodilator compound, Fabre et al. (4) described a similar behavior in terms of arterial vasoreactivity and neovascularization in response to both compounds. These data, as ours, suggest that in chronic ischemia, vasodilator, and angiogenic effects are probably linked. Therefore, in the evaluation of chronic experimental models, it is probably difficult to discriminate between a vasodilator effect followed by angiogenesis or angiogenesis followed by improvement of vasoreactivity.

In conclusion, our study describes a new model and provides strong evidence for the local involvement of ET- 1 in the pathogenesis of chronic critical muscular ischemia. The role of ET-1 in chronic muscle ischemia was demonstrated by the tissue induction of endothelins, ECE-1 and ET receptors expression, and by the improvement of tissue ischemia with endothelin receptor antagonists. These experimental data suggest that blockade of the endothelin system may be of interest for improving, at least in part, critical muscle ischemia in patients.

\section{Acknowledgments}

The authors thanks Dr. M. Osborne-Pellegrin and Dr. L.J. Feldman for reviewing the manuscript. This was supported by INSERM and by a grant of the Fondation de France.

\section{References}

1. European Working Group of Critical Leg Ischemia. (1991) Second European Consensus Document on chronic critical leg ischemia. Circulation 84: IV1-IV26.

2. Isner JM, Walsh K, Symes J, et al. (1995) Arterial gene therapy for therapeutic angiogenesis in patients with peripheral artery disease [news]. Circulation 91: 2687-2692.

3. Isner JM, Baumgartner I, Rauh G, et al. (1998) Treatment of thromboangiitis obliterans (Buerger's disease) by intramuscular gene transfer of vascular endothelial growth factor: preliminary clinical results. J. Vasc. Surg. 28: 964-973; discussion 973-975.

4. Fabre JE, Rivard A, Magner M, Silver M, Isner JM. (1999) Tissue inhibition of angiotensinconverting enzyme activity stimulates angiogenesis in vivo. Circulation 99: 3043-3049.

5. Yanagisawa $M$, Kurihara H, Kimura $S$, et al. (1988) A novel potent vasoconstrictor peptide produced by vascular endothelial cells [see comments]. Nature 332: 411-415.
6. Levin ER. (1995) Endothelins. N. Engl. J. Med. 333: 356-363.

7. Caligiuri G, Levy B, Pernow J, Thoren P, Hansson GK. (1999) Myocardial infarction mediated by endothelin receptor signaling in hypercholesterolemic mice. Proc. Natl. Acad. Sci. USA 96: 6920-6924.

8. Shigeno T, Clozel M, Sakai S, Saito A, Goto K. (1995) The effect of bosentan, a new potent endothelin receptor antagonist, on the pathogenesis of cerebral vasospasm. Neurosurgery 37: 87-90; discussion 90-91.

9. Tonnessen T, Christensen G, Oie E, et al. (1997) Increased cardiac expression of endothelin-1 mRNA in ischemic heart failure in rats. Cardiovasc. Res. 33: 601-610.

10. Guo Y, Cernacek P, Giaid A, Hussain SN. (1998) Production of endothelins by the ventilatory muscles in septic shock. Am. J. Respir. Cell Mol. Biol. 19: 470-476.

11. Hvaal K, Oie E, Attramadal H, et al. (1998) Endothelin-1 is upregulated during skeletal muscle ischemia and reperfusion. J. Orthop. Res. 16: 128-135.

12. Wang QD, Li XS, Lundberg JM, Pernow J. (1995) Protective effects of non-peptide endothelin receptor antagonist bosentan on myocardial ischaemic and reperfusion injury in the pig. Cardiovasc. Res. 29: 805-812.

13. Hvaal K, Mathisen SR, Svindland A, Nordsletten L, Skjeldal S. (1999) Protective effect of the endothelin antagonist Bosentan against ischemic skeletal muscle necrosis. Acta Orthop. Scand. 70: 293-297.

14. Clozel M, Breu V, Burri K, et al. (1993) Pathophysiological role of endothelin revealed by the first orally active endothelin receptor antagonist. Nature 365: 759-761.

15. Nilsson GE, Tenland T, Obert PA. (1980) A new instrument for continuous measurement of tissue blood flow by light beating spectroscopy. IEEE Trans. Biomed. Eng. 27: 12-19.

16. Nilsson GE, Tenland T, Oberg PA. (1980) Evaluation of a laser Doppler flowmeter for measurement of tissue blood flow. IEEE Trans. Biomed. Eng. 27: 597-604.

17. Carlson BM, Gutmann E. (1975) Regeneration in free grafts of normal and denervated muscles in the rat: morphology and histochemistry. Anat. Rec. 183: 47-62.

18. Forbes RD, Cernacek P, Zheng S, Gomersall M, Guttmann RD. (1996) Increased endothelin expression in a rat cardiac allograft model of chronic vascular rejection. Transplantation 61: 791-797.

19. Chomczynski P, Sacchi N. (1987) Single-step method of RNA isolation by acid guanidinium thiocyanate-phenol-chloroform extraction. Anal. Biochem. 162: 156-159.

20. Bloch KD, Eddy RL, Shows TB, Quertermous T. 
(1989) cDNA cloning and chromosomal assignment of the gene encoding endothelin 3. J. Biol. Chem. 264: 18156-18161.

21. Wenzel RR, Fleisch M, Shaw S, et al. (1998) Hemodynamic and coronary effects of the endothelin antagonist bosentan in patients with coronary artery disease. Circulation 98: 2235-2240.

22. Kiowski W, Sutsch G, Hunziker P, et al. (1995) Evidence for endothelin-1-mediated vasoconstriction in severe chronic heart failure. Lancet 346: 732-736.

23. Skjeldal S, Grogaard B, Reikeras O, Muller C, Torvik A, Svindland A. (1991) Model for skeletal muscle ischemia in rat hindlimb: evaluation of reperfusion and necrosis. Eur. Surg. Res. 23: 355-365.

24. Yang HT, Deschenes MR, Ogilvie RW, Terjung RL. (1996) Basic fibroblast growth factor increases collateral blood flow in rats with femoral arterial ligation. Circ. Res. 79: 62-69.

25. Li H, Chen SJ, Chen YF, et al. (1994) Enhanced endothelin-1 and endothelin receptor gene expression in chronic hypoxia. J. Appl. Physiol. 77: 1451-1459.

26. Gu J, Pinheiro JM, Yu CZ, et al. (1991) Detection of endothelin-like immunoreactivity in epithelium and fibroblasts of the human umbilical cord. Tissue Cell. 23: 437-444.

27. Chakrabarti S, Gan XT, Merry A, Karmazyn M, Sima AA. (1998) Augmented retinal endothelin-1, endothelin-3, endothelin A and endothelin B gene expression in chronic diabetes. Curr. Eye Res. 17: 301-307.

28. Miyauchi T, Yanagisawa M, Tomizawa T, et al. (1989) Increased plasma concentrations of endothelin-1 and big endothelin-1 in acute myocardial infarction [letter]. Lancet 2: 53-54.

29. Edward JD, Dovgan PS, Rowley JM, Agrawal DK, Thorpe PE, Adrian TE. (1994) Endothelin-1 levels in ischemia, reperfusion, and haemorrhagic shock in the canine infrarenal aortic revascularisation model. Eur. J. Vasc. Surg. 8: 729-734.

30. Frelin C, Guedin D. (1994) Why are circulating concentrations of endothelin-1 so low? Cardiovasc. Res. 28: 1613-1622.

31. Ozaki S, Ohwaki K, Ihara M, Fukuroda T, Ishikawa K, Yano M. (1995) ETB-mediated regulation of extracellular levels of endothelin-1 in cultured human endothelial cells. Biochem. Biophys. Res. Commun. 209: 483-489.

32. Dupuis J, Goresky CA, Fournier A. (1996) Pulmonary clearance of circulating endothelin-1 in dogs in vivo: exclusive role of ETB receptors. $J$. Appl. Physiol. 81: 1510-1515.

33. Wagner OF, Christ G, Wojta J, et al. (1992) Polar secretion of endothelin-1 by cultured endothelial cells. J. Biol. Chem. 267: 16066-16068.

34. Karam H, Bruneval P, Clozel JP, Loffler BM, Bariety J, Clozel M. (1995) Role of endothelin in acute renal failure due to rhabdomyolysis in rats. J. Pharmacol. Exp. Ther. 274: 481-486.

35. Roux S, Loffler BM, Gray GA, Sprecher U, Clozel M, Clozel JP. (1995) The role of endothelin in experimental cerebral vasospasm. Neurosurgery 37: 78-85; discussion 85-86.

36. Champion HC, Estrada LS, Estrada LN, Filep JG, Kadowitz PJ. (1998) Analysis of effects of bosentan (Ro 47-0203), a nonpeptide endothelin ETA/ETB receptor antagonist, in the hindlimb vascular bed of the caT. Can. J. Physiol. Pharmacol. 72: 141-147.

37. Clozel M, Gray GA, Breu V, Loffler BM, Osterwalder R. (1992) The endothelin ETB receptor mediates both vasodilation and vasoconstriction in vivo. Biochem. Biophys. Res. Commun. 186: 867-873.

38. Porter LP, McNamee JE, Wolf MB. (1999) Endothelin-1 induces endothelial barrier failure in the cat hindlimb. Shock 11: 111-114. 